\title{
A INCONSTITUCIONALIDADE DO PRÉVIO ESTABELECIMENTO DA PENA NOS ACORDOS DE COLABORAÇÃO PREMIADA REGIDOS PELA LEI 12.850/2013
}

\author{
Matheus Felipe de Castro ${ }^{1}$ \\ Luciano Zanetti ${ }^{2}$
}

\begin{abstract}
RESUMO: O artigo tematiza a colaboração premiada disciplinada pela Lei $12.850 / 2013$. O problema de pesquisa questiona a constitucionalidade do estabelecimento de pena no acordo, sem que tramite um devido processo legal e o magistrado, ao final, analise a aplicação da medida negociada na sentença. A hipótese é que a Constituição Federal de 1988 não admite essa antecipação. A área de pesquisa é o Direito Penal e Processual Penal constitucionais. A metodologia utilizada é o estudo de caso julgado pelo Supremo Tribunal Federal do Brasil.
\end{abstract}

PALAVRAS-CHAVE: colaborações premiadas; devido processo legal; antecipação de pena; processo penal negocial.

\section{THE UNCONSTITUTIONALITY OF THE PREVIOUS SETTLEMENT OF THE PENALTY IN PREMIUM COLLABORATION AGREEMENTS GOVERNED BY LAW 12.850 / 2013}

\begin{abstract}
The article deals with the award-winning collaboration disciplined by Law 12.850/2013. The research problem questions the constitutionality of the establishment of penalty in the agreement, without due process of legal process and the magistrate, in the end, analyze the application of the measure negotiated in the sentence. The hypothesis is that the Federal Constitution of 1988 does not allow this anticipation. The research area is constitutional criminal and procedural criminal law. The methodology used is the case study judged by the Brazilian Supreme Court.
\end{abstract}

KEYWORDS: Award-winning collaborations; due process of law; anticipation of penalty; negotiating criminal proceedings.

\section{INTRODUÇÃO}

Este artigo tem por objeto o instituto da colaboração premiada, conforme regulamentado pela Lei $12.850 / 2013$, se propondo a verificar, no Direito brasileiro, se é

\footnotetext{
${ }^{1}$ Doutor em Direito pela UFSC-Universidade Federal de Santa Catarina (2009) e Pós-Doutor em Direito pela UnB-Universidade de Brasília (2017). Professor de Direito Processual Penal na graduação em Direito e no Programa de Pós-graduação profissional (mestrado) em Direito e Acesso à Justiça da UFSC e professor de Criminologia na graduação em Direito e no Programa de Pós-graduação (mestrado e doutorado) da UNOESCUniversidade do Oeste de Santa Catarina. Coordenador do Cautio Criminalis-Grupo de Estudos e Pesquisas em Realidade do Sistema Penal Brasileiro. E-mail: matheusfelipedecastro@gmail.com.

${ }^{2}$ Mestre em Direito pela Universidade Federal de Santa Catarina - UFSC, especialista em Direito Civil pela Universidade Anhanguera-Uniderp, professor de Direito Civil e Direito Processual Civil do Instituto de Ensino Superior da Grande Florianópolis, membro do Grupo de Estudos Cautio Criminalis, da Universidade Federal de Santa Catarina - UFSC, servidor do Tribunal de Justiça de Santa Catarina. E-mail: zanettiluciano1@ gmail.com.
} 
juridicamente possível, nos acordos de colaboração premiada, prévia e antecipadamente a fixação da pena a ser cumprida pelo colaborador.

A hipótese é que a Constituição Federal de 1988, na qualidade de regente dos sistemas penal e processual penal brasileiros, não admite essa antecipação, porque malfere os princípios do devido processo legal, do juiz natural, da legalidade, da superioridade ética do Estado, bem como conflita com o sistema acusatório delineado na Constituição.

O objetivo é verificar se é juridicamente possível a prévia fixação de sanção penal ao colaborador nos acordos de colaboração premiada, tendo como campos teóricos de pesquisa o Direito Penal e Direito Processual Penal constitucionais, sendo o estudo dividido em quatro seções, a saber.

$\mathrm{Na}$ primeira seção será feita a apresentação de um caso, decidido pelo Supremo Tribunal Federal, consistindo num pedido de homologação de acordo de colaboração premiada não foi acolhido pelo Ministro Relator, que se absteve de homologá-lo sob o argumento de que continha diversas inconstitucionalidades e ilegalidades.

Já na segunda seção, são apontadas origens e influências do instituto tanto do ordenamento jurídico brasileiro como do Direito estrangeiro, assim como abordada a sua natureza jurídica conforme regramento da Lei 12.850/2013 (negócio jurídico em sentido lato e causa de aumento/diminuição de penal) como do Direito Processual Penal (negócio jurídico processual, meio de obtenção de prova e meio de defesa).

Na terceira seção, será apresentado o procedimento delineado pela Lei 12.850/2013 para o pleito homologatório do acordo, bem como se discorrerá acerca da competência para o juízo de sindicalidade do acordo e, ao fim, se discorrerá acerca do ato jurisdicional de homologação do acordo, os requisitos legais, o momento de realização bem como de suas consequências.

Por fim, a quarta e última seção tratará dos vícios de constitucionalidade e legalidade em razão da antecipação da pena nos acordos de colaboração premiada regidos pela Lei 12.850/2013, trazendo a crítica que a doutrina especializada tem feito sobre a questão.

A metodologia utilizada terá orientação indutiva, visando a estabelecer conceitos gerais para o tema. O estudo de caso concreto julgado pelo Supremo Tribunal Federal concretizará essa proposta metodológica.

\section{UMA PIONEIRA DECISÃO DO SUPREMO TRIBUNAL FEDERAL}


Em 15 de setembro de 2017 foi protocolizado junto ao Supremo Tribunal Federal um pedido de homologação de colaboração premiada, firmado entre o Ministério Público Federal e Renato Barbosa Rodrigues Pereira, registrado sob n. PET 7.265-DF ${ }^{3}$.

No instrumento do pacto, o colaborador admitiu ter cometido diversos delitos, em conjunto com outras pessoas que compunham uma organização criminosa, a qual teria praticado diversos crimes contra a administração pública, a ordem tributária, lavagem e ocultação de bens, direitos ou valores e organização criminosa, se obrigando o colaborador a auxiliar na apuração da repercussão desses crimes nas esferas administrativa, civil, tributária e disciplinar.

O procedimento tramitou no Supremo Tribunal Federal em virtude de que uma das pessoas delatadas ocupava, à época, uma cadeira no Senado Federal, portanto detentora de prerrogativa de foro perante aquela Corte.

Foi mencionado pelas partes que o colaborador não renunciou aos direitos e garantias constitucionais (direito ao silêncio, direito de não produzir prova contra si mesmo, direito ao contraditório, à ampla defesa, ao devido processo legal, etc.), mas, voluntariamente, movido pelo desejo de obter benefícios legais em colaboração à justiça, deixava de exercê-los.

Dentre as obrigações assumidas pelo colaborador, destacaram-se: identificação dos autores, coautores e partícipes das diversas organizações criminosas que o colaborador tivesse conhecimento; revelação da estrutura hierárquica e a divisão de tarefas das organizações criminosas que integrou ou tinha conhecimento; recuperação total ou parcial do produto e/ou do proveito das infrações penais praticadas pela organização criminosa; identificação das pessoas naturais ou jurídicas utilizadas pela organização criminosa no cometimento dos delitos; fornecimento de documentos e outras provas materiais acerca dos delitos afetos à colaboração; cooperar, sempre que solicitado, mediante comparecimento pessoal e às suas expensas, em quaisquer das sedes do Ministério Público Federal, Polícia Federal, Receita Federal do Brasil, a fim de analisar documentos, provas e pessoas, bem como prestar depoimentos e auxiliar peritos na análise criminal de fatos que sejam objeto da colaboração; entregar todos os documentos, papéis e escritos, fotografias, bancos de dados, arquivos eletrônicos, senhas de e-mails de que dispunha, quer sob a guarda de terceiros sob suas ordens; renúncia à garantia contra a autoincriminação e ao direito ao silêncio.

\footnotetext{
${ }^{3}$ Disponível em: <http://portal.stf.jus.br/processos/detalhe.asp?incidente=5265852>. Acesso em: 17 de julho de 2019.
} 
Já em contrapartida, ficou assentado que o colaborador receberia, considerando que confessadamente integrou uma organização criminosa, mas não possuía antecedentes criminais e foi o primeiro a prestar efetiva contribuição sobre a maioria dos fatos ilícitos revelados, uma vez cumpridas integralmente as condições impostas no acordo para recebimento dos benefícios: o perdão judicial de todos os crimes, à exceção daqueles praticados por ocasião da campanha eleitoral para o Governo do Estado do Rio de Janeiro no ano de 2014, consubstanciados nos tipos penais descritos no art. 350 do Código Eleitoral, no art. $1^{\circ}, \S 2^{\circ}$, inciso I, da Lei no 9.613/98 e art. 22, parágrafo único, da Lei no 7.492/86, pelos quais a pena acordada seria a condenação à pena unificada de 4 anos de reclusão, nos processos penais que viessem a ser instaurados com esteio nos fatos objetos do acordo, em regime fechado, a ser cumprido em estabelecimento prisional.

Concordaram as partes que a pena de reclusão prevista seria cumprida na forma recolhimento noturno, pelo prazo de um ano, consubstanciado no recolhimento domiciliar de segunda-feira a domingo, a partir das $20 \mathrm{~h}$ até as $6 \mathrm{~h}$, reservada a possibilidade da realização de viagens nacionais e internacionais a trabalho mediante prévia autorização do juízo competente, assim como a prestação de serviços à comunidade traduzida no atendimento por vinte horas semanais em entidade filantrópica pelo prazo de três anos, devendo tal pena ser executada no prazo máximo de quatro anos.

O colaborador comprometeu-se, ainda, ao pagamento de $\mathrm{R} \$ 1.500 .000,00$ (um milhão e quinhentos mil reais) mediante depósito em conta judicial, cuja destinação seria definida posteriormente, a título de multa penal e reparação de danos, quantia que deveria ser recolhida em até dezoito meses, corrigida e adicionada de juros até o dia em que fosse paga.

Foi também avençado que o colaborador iniciaria o cumprimento das penas logo após a homologação judicial do acordo.

Finalmente, foi acordado pelas partes que, uma vez homologado o pacto e tão logo alcançado o teto máximo de condenação previsto, o Ministério Público Federal proporia a suspensão de ações penais, inquéritos policiais e procedimentos investigatórios criminais que estivessem em curso em desfavor do colaborador, bem como a suspensão dos respectivos prazos prescricionais pelo lapso temporal de dez anos.

Após a ouvida do colaborador o acordo foi submetido, no Supremo Tribunal Federal, à apreciação do Ministro designado Relator, Ricardo Lewandowski, o qual não homologou o acordo, sustentando que do modo como estava acordado, principalmente pelo fato de que as 
partes, prévia e antecipadamente, já fixaram quais seriam as penalidades, o quantum, o regime de cumprimento e o prazo prescricional, o pacto malferiria preceitos capitais do ordenamento jurídico brasileiro (sistema acusatório, princípio do juiz natural, princípio da legalidade, etc.).

Ao fim, foi determinada a restituição do acordo ao Ministério Público Federal e ao colaborador para que, querendo, o adequassem à Constituição e às leis brasileiras.

\section{A COLABORAÇÃO PREMIADA REGIDA PELA LEI 12.850/2013:} APLICABILIDADE, INSTITUTOS AFINS NO DIREITO BRASILEIRO E ESTRANGEIRO E NATUREZA JURÍDICA

O instituto da colaboração premiada tem sido aplicado com bastante frequência nos últimos cinco anos, especialmente no âmbito da conhecida Operação Lava Jato, intentada pelo Ministério Público Federal e Polícia Federal sob o argumento de combater crimes relacionados ao desvio de dinheiro ocorrido em diversos órgãos e empresas públicas federais, com a participação de funcionários públicos e agentes de Estado.

Até onde se sabe, a primeira colaboração premiada ocorrida após a vigência da Lei 12.850/2013, foi a de Paulo Roberto Costa, bastante noticiada na imprensa nacional, cujo termo de acordo foi firmado em 27 de agosto de $2014^{4}$, seguida da firmada por Alberto Yussef, em 24 de setembro do mesmo ano ${ }^{5}$. De lá para cá, muitos outros acordos foram entabulados, tanto por funcionários públicos, políticos e bem como por empresários.

Para se ter uma ideia da dimensão dessa operação investigativa em números, segundo dados oficiais postados no sítio eletrônico do Ministério Público Federal ${ }^{6}$, até julho de 2019, somente no Estado do Paraná, um dos principais centros da Operação, ocorreram: dois mil quatrocentos e setenta e seis procedimentos instaurados; setecentos e cinquenta e quatro pedidos de cooperação internacional; cento e oitenta e quatro acordos de colaboração premiada firmados por pessoas naturais; onze acordos de leniência; um termo de ajustamento de conduta; noventa e nove acusações criminais contra quatrocentos e trinta e oito pessoas distintas, das quais cento e cinquenta e nove foram condenadas; dez acusações por

\footnotetext{
${ }^{4}$ Uma cópia do termo de acordo pode ser encontrada em: <https://s.conjur.com.br/dl/acordo-delacao-premiadapaulo-roberto.pdf $>$. Acesso em: 22 de julho de 2019.

${ }_{5}$ Uma cópia do termo de acordo pode ser encontrada em: <https://politica.estadao.com.br/blogs/faustomacedo/wp-content/uploads/sites/41/2015/01/acordodela\%C3\%A7\%C3\%A3oyoussef.pdf >. Acesso em: $22 \mathrm{de}$ julho de 2019.

${ }^{6}$ Disponível

em:

<http://www.mpf.mp.br/grandes-casos/caso-lava-jato/atuacao-na-1ainstancia/parana/resultado>. Acesso em: 28 de agosto de 2019.
} 
improbidade administrativa contra sessenta e três pessoas naturais, dezoito empresas e três partidos políticos.

Já quando se fala em volume de recursos envolvidos, os números são ${ }^{7}$ : R \$ 40,3 bilhões (incluindo multas) de valor total ressarcido; $\mathrm{R} \$ 6,4$ bilhões de pagamentos de propina apurados; R \$ 13 bilhões alvos de recuperação por acordos de colaboração premiada, sendo R \$ 846,2 milhões objeto de repatriação e $\mathrm{R} \$ 3,2$ bilhões em bens bloqueados dos réus na operação.

A Lei $12.850 / 2013^{8}$, a qual definiu para fins legais o conceito de organização criminosa, dispondo também sobre a investigação criminal, os meios de obtenção da prova, infrações penais correlatas e o procedimento criminal correspondente, em sua Seção I (artigos $4^{\mathrm{o}}$ a $7^{\circ}$ ), disciplina o instituto da colaboração premiada.

Por meio dela, como está previsto no texto do seu artigo $4^{\circ}$, o juiz poderá, a requerimento das partes, conceder o perdão judicial, reduzir em até $2 / 3$ (dois terços) a pena privativa de liberdade ou substituí-la por restritiva de direitos daquele que tenha colaborado efetiva e voluntariamente com a investigação e com o processo criminal, desde que dessa colaboração advenha um ou mais resultados previstos nos incisos I a V do mesmo artigo ${ }^{9}$.

Há, ainda, dois outros benefícios possíveis também previstos na Lei (art. $4^{\circ}, \S \S 4^{\circ} \mathrm{e}$ $5^{\circ}$ ), consistentes, respectivamente, em: (a) poder o Ministério Público deixar de oferecer a denúncia contra o colaborador desde que ele não seja o líder da organização criminosa e seja o primeiro a colaborar; e (b) possibilidade de a pena poderá ser reduzida até a metade ou será admitida a progressão de regime ainda que ausentes os requisitos objetivos, caso a colaboração ocorra após a sentença penal condenatória.

Por meio da colaboração premiada, tanto o Ministério Público quando o delegado de polícia (com a anuência de um representante daquele), poderiam policitar benefícios legais ao integrante da organização criminosa, o qual, em contrapartida, oferta informações visando ao atingimento de algum dos resultados almejados e previstos no instrumento firmado, revelando um novo espaço de consenso dentro do processo penal brasileiro.

\footnotetext{
${ }^{7}$ Idem.

8 Disponível em: <http://www.planalto.gov.br/ccivil_03/_Ato2011-2014/2013/Lei/L12850.htm>. Data do acesso: 23 de julho de 2019.

${ }^{9}$ I - a identificação dos demais coautores e partícipes da organização criminosa e das infrações penais por eles praticadas; II - a revelação da estrutura hierárquica e da divisão de tarefas da organização criminosa; III - a prevenção de infrações penais decorrentes das atividades da organização criminosa; IV - a recuperação total ou parcial do produto ou do proveito das infrações penais praticadas pela organização criminosa; V - a localização de eventual vítima com a sua integridade física preservada.
} 
Contudo, diversamente de outros institutos parecidos - a exemplo da transação penal regulamentada pela Lei 9.099/95, que possui um viés despenalizador -, a colaboração tem caráter penalizante (SANTOS, 2019, p. 19), uma vez que, por meio dela, o Estado acusador persegue o maior número de agentes possível, com o menor esforço e dispêndio de recursos públicos e, para tanto, conta com a participação de um dos coautores ou partícipes, o qual detém informações privilegiadas, sob o argumento de alcançar outros membros da organização criminosa.

Sua instrumentalidade tem se mostrado "eficaz" para o exercício do poder punitivo, na medida em que provoca uma espécie de "anulação do ônus de provar" que, classicamente, pertenceria no Processo Penal ao órgão acusador no curso de um devido processo legal. A ameaça de um processo penal, num ambiente de condenações "esperadas", seria móbil suficiente para "forçar" a aceitação de um acordo de colaboração premiada por parte de alguns réus, dispensando o Ministério Público do ônus de provar a culpabilidade do acusado no curso do procedimento.

No entanto, ainda que se argumente que o Estado estaria justificado ao lançar mão da colaboração premiada, pois visaria a um bem maior (descoberta de crimes e punição de membros de organizações criminosas) o abandono de regras básicas de processo penal constitucional em face de um colaborador (acusação formal, defesa, coleta de provas, sentença e trânsito em julgado), foi levantada pelo Ministro relator Ricardo Lewandowski em sua decisão, constituindo um dos principais motivos para que o acordo aqui em estudo deixasse de ser homologado.

O fato é que, como o advento da Lei 12.850/2013, como observa Gustavo Henrique Badaró, houve uma transição de paradigmas no processo penal:

A centralidade da legitimação do exercício do poder de punir de um instrumento cognitivo fundado no saber construído em contraditório, com o funcionamento de um mecanismo dialético de verificação e confronto entre tese e antítese, baseado na prova produzida que suporte cada uma delas, para um modelo em que haverá apenas uma "verdade" preestabelecida por uma escolha discricionária (BADARÓ, 2017, p. 143).

O pano de fundo para essa mudança de paradigma - da investigação e cognição oficiais, segundo as regras do devido processo legal, com coleta de provas e julgamento tradicionais, para uma forma "negocial", com comércio de informações e estabelecimento da sanção penal, apresenta uma clara apropriação das formas mercantis do neoliberalismo para o interior das formas jurídicas: 
A economia política tem caráter utilitário e pragmático, se constituindo em uma técnica de enriquecimento do Estado. Para esse fim, os Estados contemporâneos se instituíram como Estados mercantis em suas políticas externas e Estados de Polícia em suas gestões internas. Tanto em uma direção quanto em outra, a economia política tende a liberar o poder do Estado ao invés de contê-lo, como acontecia quando o poder de legitimação era o Direito. (CASTRO, 2018, p. 216)

Todavia, é um fenômeno complexo e que assume diversas faces, tanto no plano material como no processual, possuindo origens em categorias jurídicas advindas do direito estrangeiro, bem como detém natureza jurídica múltipla, a depender do ângulo de visão que o observador se encontra e deseja visualizá-lo.

Portanto, além da substituição do Direito pela Economia política como técnica de controle e implementação de políticas e gestões públicas, conflui para o estado atual da cultura do consenso e da mercantilização no seio do processo penal a adoção de categorias jurídicas vindas do direito estrangeiro, principalmente o plea bargain norte-americano e o patteggiamento italiano, cujos preceitos e fundamentos paulatinamente foram se fundindo no Direito Processual Penal brasileiro, revelando uma nova realidade.

\subsection{Institutos afins no Direito brasileiro e estrangeiro}

A despeito da Lei 12.850/2013, outras leis penais brasileiras já continham caracteres de consenso, como, por exemplo: (a) Lei $7.492 / 86^{10}$ (define crimes Sistema Financeiro Nacional), prevendo, no art. $25, \S 2^{\circ}$, prevendo redução de pena de um a dois terços para o coautor que auxiliar as investigações; (b) Lei 8.072/1990 ${ }^{11}$ (Lei dos Crimes Hediondos), a qual, no Parágrafo único do seu art. $8^{\circ}$, prevê redução da pena de um a dois terços ao agente que colaborar; (c) Lei 8.137/1990 ${ }^{12}$ (Lei dos Crimes Tributários), a qual determina que nos crimes nela previstos, co-autor ou partícipe que revelar à autoridade policial ou judicial os detalhes dos delitos e seus autores terá a sua pena reduzida de um a dois terços; (d) Lei 9.099/1995 ${ }^{13}$, (Lei Juizados Especiais Cíveis e Criminais) que trouxe os institutos da transação penal e da suspensão condicional do processo (respectivamente artigos 76 e 89), ambos partindo da cultura do consenso.

Contudo, apesar de o ordenamento jurídico brasileiro já contemplar previsões legais de caráter consensual relativamente ao processo penal, grande parte da inspiração do

\footnotetext{
${ }^{10}$ Disponível em: <http://www.planalto.gov.br/ccivil_03/leis/L7492.htm>. Acesso em: 26 de julho de 2019.

${ }^{11}$ Disponível em: <http://www.planalto.gov.br/ccivil_03/leis/L8072.htm>. Acesso em 26 de julho de 2019.

${ }^{12}$ Disponível em: <http://www.planalto.gov.br/ccivil_03/leis/L8137.htm>. Acesso em 26 de julho de 2019.

${ }^{13}$ Disponível em: < http://www.planalto.gov.br/ccivil_03/leis/L9099.htm>. Acesso em 26 de julho de 2019.
} 
legislador brasileiro para disciplinar a colaboração premiada veio do Direito estrangeiro, mais precisamente do modelo norte-americano, por natureza pragmático, menos teórico, e insuflado pela visão negocial da pena, importando mais o utilitarismo e a eficiência do sistema no atingimento dos fins e metas. É o que ensina Marcos Paulo Dutra Santos ao destacar:

Por essa razão, é inapropriado trabalhar, por exemplo, com os princípios da obrigatoriedade e da oportunidade da ação penal pública quando se estuda o ordenamento processual norte-americano. Nos Estados Unidos da América, jamais houve a preocupação, ou mesmo o interesse, de se teorizar o exercício do direito de ação. Todo ordenamento jurídico, como manifestação cultural que é, reflete a ideologia do país onde está inserto, e o utilitarismo ianque definitivamente não se afina com as construções teóricas e rebuscadas, sem reflexo prático e imediato (SANTOS, 2019, p. 41).

Exemplo de como esse modelo de justiça criminal funciona está no caso Santobello versus New York, 404 U.S 257, julgado pela Suprema Corte Americana no ano de 1971, como conta Rodrigo Capez, ocasião em que um dos juízes assim se manifestou:

[...] a disposição sobre acusações criminais por acordo entre o promotor e o acusado é um componente essencial da administração da Justiça. Administrado de forma adequada há que ser encorajado. Se toda acusação criminal estiver sujeita a um julgamento completo, os Estados e o Governo Federal necessitariam multiplicar em muitas vezes o número de juízes e de instalações de cortes. (CAPEZ, 2017, p. 228)

Por isso, se pode afirmar que um primeiro caractere do paradigma de Justiça vigente nos Estados Unidos da América está na negociabilidade da pena como regra, importando menos a verdade dos fatos e do que o resultado útil (para o poder punitivo) e rápido do caso.

Esse aspecto foi considerado pelo Ministro relator Ricardo Lewandowski, na decisão aqui em estudo ${ }^{14}$, ao apontar que uma das diferenças centrais entre o sistema romanogermânico, que inspirou o processo penal brasileiro, e o anglo-saxão, que foi base para o Direito norte-americano, é que este último concebe o processo criminal como um instrumento para reger disputas entre duas partes (a acusação e a defesa), perante um juiz, cujo papel é eminentemente passivo, ao passo que o romano-germânico entende a ação penal como uma forma de apuração oficial dos fatos, a qual tem por finalidade lograr a apuração da verdade .

Há ainda outra característica naquele modelo processual, a qual é trazida por Ana Lara Camargo de Castro, anotando que é da essência desse sistema (adversarial) que a solução dos conflitos se dê por meio de disputas de pontos de vista tanto sobre os fatos como sobre o direito, perante árbitros neutros e passivos. Em suas próprias palavras: “O sistema adversarial

\footnotetext{
${ }^{14}$ Vide p. 18-19 da decisão referenciada.
} 
se fundamenta na perspectiva de que a verdade se estabelece na competição do mercado de ideias (marketplace of ideas), no choque das argumentações (adversarial clasch) " (CASTRO, 2019, p. 25).

Já no direito italiano tem-se o institudo do "patteggiamento" (acordo judicial), o qual tanto pode se dar em face do rito processual quanto da pena, em algumas hipóteses definidas em lei. O Código de Processo Penal daquele País, no seu Título II, chamado de Applicazione Della Pena su Richiesta Delle Parti (Aplicação da Pena a Pedido das Partes), disciplina as hipóteses em que as partes (acusação e defesa), podem avençar acerca da pena a ser infligida. Em seu art. 444 assim determina ${ }^{15}$ :

\begin{abstract}
Art. 444 L'imputato e il pubblico ministero possono chiedere al giudice l'applicazione, nella specie e nella misura indicata, di una sanzione sostitutiva o di una pena pecuniaria, diminuita fino a un terzo, ovvero di una pena detentiva quando questa, tenuto conto delle circostanze e diminuita fino a un terzo, non supera cinque anni soli o congiunti a pena pecuniaria ${ }^{16}$.
\end{abstract}

Conta Nereu Giacomolli que o patteggiamento nasceu no ano de 1981, sob forte resistência doutrinária, em virtude de que poderia ofender os princípios da obrigatoriedade da ação penal, do direito à defesa etc., destinando-se a delitos de pequena monta (GIACOMOLLI, 2006, p. 257).

O próprio magistrado, com o consentimento do imputado ou, ainda, a requerimento deste, poderia aplicar uma pena substitutiva (pecuniária ou liberdade vigiada), extinguindo-se o processo sem que a decisão pudesse ser impugnada. Por isso, inclusive, houve divisão na doutrina se realmente estar-se-ia tratando de medida de natureza penal ou administrativa, prevalecendo decisão da Corte maior italiana de que a primeira hipótese seria correta, ainda que com efeitos limitados.

Esses são os dois principais institutos inspiradores da colaboração premiada, cada qual com suas especificidades, mas tendo um ponto em comum: a implementação do consenso no seio do processo penal, tanto sobre o rito processual, mas principalmente, sobre a própria pena. Retornando à colaboração premiada em si, adiante se fará uma incursão pela sua complexa natureza, que levará em conta tanto aspectos processuais como materiais.

\footnotetext{
${ }^{15}$ Disponível em: <https://www.brocardi.it/codice-di-procedura-penale/libro-sesto/titolo-ii/art444.html>. Acesso em: 4 de julho de 2019.

${ }^{16} \mathrm{O}$ imputado ou o ministério público podem pedir ao juiz a aplicação, na espécie e na medida indicada, de uma sanção substitutiva ou de uma pena pecuniária, diminuída de até um terço, ou de uma pena privativa de liberdade quando esta, tendo em conta as circunstâncias, diminuída de até um terço, não excede cinco anos isoladamente ou em conjunto com a pena pecuniária (tradução livre).
} 


\subsection{A complexa natureza jurídica da colaboração premiada}

A primeira e mais comum visão que se tem da colaboração premiada é que seria um meio de obtenção de prova, e não um meio de prova propriamente dito. Isto se dá porque a Lei 12.850/2013 estabelece que nenhuma sentença condenatória poderá ser proferida com fundamento apenas nas declarações de agente colaborador ( $\operatorname{art.} 4^{\mathrm{o}}, \S 16^{17}$ ).

É o entendimento que, atualmente, prevalece nas decisões do Supremo Tribunal Federal. Por todos, veja-se a decisão proferida no $\mathrm{HC} 127.483 / \mathrm{PR}^{18}$, da relatoria do Ministro Dias Toffolli:

[...] 4. A colaboração premiada é um negócio jurídico processual, uma vez que, além de ser qualificada expressamente pela lei como "meio de obtenção de prova", seu objeto é a cooperação do imputado para a investigação e para o processo criminal, atividade de natureza processual, ainda que se agregue a esse negócio jurídico o efeito substancial (de direito material) concernente à sanção premial a ser atribuída a essa colaboração.

Ao mesmo tempo, quando se visualiza o acordo em si e não o que ela representa para o processo penal, se pode dizer também que é um negócio jurídico processual, por implicar um acordo de vontades dirigido a um objeto (as cláusulas) e uma finalidade.

A Lei 12.850/2013 apresenta diversas expressões que denotam essa realidade, a saber: "negociações" (art. $\left.4^{\circ}, \S 6^{\circ}\right)$, "acordo" (art. $4^{\circ}, \S \S 7^{\circ}, 9^{\circ}$ e 11$)$ "proposta" (art. $4^{\mathrm{o}}, \S 8^{\mathrm{o}} \mathrm{e}$ 10), de modo que, consoante o posicionamento de Rogério Filippetto e Luísa Carolina Vasconcelos Chagas Rocha:

Trata-se de verdadeiro negócio jurídico processual personalíssimo ou medida que, para além de assegurar o direito do agente colaborador de usufruir dos benefícios oferecidos, constitui garantia da própria persecução penal, que contará com a participação de um agente vinculado ao acordo, e, portanto, mais comprometido com a verdade (FILIPPETTO, 2017, p. 145).

Não obstante, André Luís Callegari e Raul Marques Linhares, falando do tema, lembram que "A ampla liberdade de disposição sobre direitos que é própria dos negócios privados aparece de forma significativamente restringida no acordo de colaboração premiada, devido à sua natureza pública (contrato de Direito Público)” (CALLEGARI, 2019, p. 23).

Além disso, também é encontrado na doutrina o pensamento de que a colaboração premiada é um meio de defesa, uma vez que visaria "obter benefícios legais, como a melhor

\footnotetext{
${ }^{17}$ Disponível em: <http://www.planalto.gov.br/ccivil_03/_ato2011-2014/2013/lei/112850.htm>. Acesso em: 28 de julho de 2019.

18 Supremo Tribunal Federal, HC 127.483/PR, Plenário, rel. Ministro Dias Toffolli, j. 27/08/2015, p. 2. Disponível em www.stf.jus.br. Acesso em: 28 de julho de 2019.
} 
opção a ser adotada pelo imputado naquele caso concreto. É claramente uma escolha racional, à luz de um cálculo utilitarista de custos e benefícios.” (MENDONÇA, 2017, p. 59).

Finalmente - e aqui está o seu caractere mais importante para a resposta ao problema de pesquisa -, a colaboração premiada é uma causa de diminuição/substituição de pena, como dispõe o artigo $4^{\circ}$, caput, da Lei 12.850/2013:

Art. $4^{\circ}$ O juiz poderá, a requerimento das partes, conceder o perdão judicial, reduzir
em até $2 / 3$ (dois terços) a pena privativa de liberdade ou substituí-la por restritiva de
direitos daquele que tenha colaborado efetiva e voluntariamente com a investigação
e com o processo criminal, desde que dessa colaboração advenha um ou mais dos
seguintes resultados ${ }^{19}$.

Para Valber Melo e Filipe Maia Broeto Nunes (MELO, 2018, p. 15), a colaboração premiada tem natureza híbrida, podendo ser analisada do ponto de vista material e processual. Quanto ao primeiro aspecto (material), ensinam que é causa de diminuição de pena, a ser analisada pelo juiz sentenciante, dentro do sistema trifásico do Código Penal ${ }^{20}$, na última fase da dosimetria da pena ${ }^{21}$.

Vistos os institutos que insuflaram o legislador brasileiro a disciplinar a colaboração premiada, bem como a sua natureza jurídica, adiante se verá acerca do procedimento e os requisitos legais para a homologação do acordo, para que ele produza efeitos no processo.

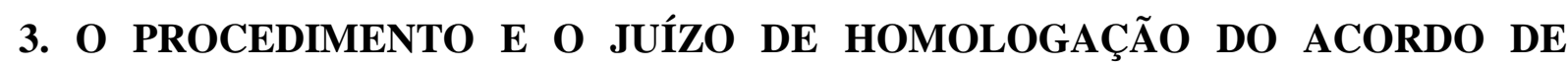 COLABORAÇÃO PREMIADA}

Segundo a Lei 12.850/2013, como regra a colaboração premiada tem início a partir de negociações preliminares entre o colaborador (assistido por seu defensor) e o Ministério Público (ou a Polícia, com a ciência daquele), pacto esse que se instrumentaliza em cláusulas, com a assinatura das partes e submissão ao magistrado/relator para homologação. É o que dispõe o art. $4^{\mathrm{o}}, \S 6^{\mathrm{o}}$ da citada Lei ${ }^{22}$ :

$\S 6^{\circ} \mathrm{O}$ juiz não participará das negociações realizadas entre as partes para a formalização do acordo de colaboração, que ocorrerá entre o delegado de polícia, o investigado e o defensor, com a manifestação do Ministério Público, ou, conforme o caso, entre o Ministério Público e o investigado ou acusado e seu defensor.

\footnotetext{
${ }^{19}$ Tais resultados já foram objeto de análise no tópico 2 , acima.

${ }^{20}$ Art. 68. A pena-base será fixada atendendo-se ao critério do art. 59 deste Código; em seguida serão consideradas as circunstâncias atenuantes e agravantes; por último, as causas de diminuição e aumento de pena.

${ }^{21}$ Os Autores, não obstante, lembram também que, no âmbito de outras legislações (v.g. acordo de leniência, instituto afim ao da Colaboração Premiada, no âmbito da Lei 12.529, que trata do Sistema Brasileiro de Defesa da Concorrência), instituto muito parecido tenha natureza jurídica de causa de extinção da punibilidade.

${ }^{22}$ Disponível em: <http://www.planalto.gov.br/ccivil_03/_ato2011-2014/2013/lei/l12850.htm>. Acesso em: 15 de julho de 2019.
} 
Depois de firmado o acordo, este é remetido ao juiz/relator competente para homologação, o qual, como determina o art. $4^{\circ}, \S 7^{\circ}$, verificará a sua regularidade, legalidade e voluntariedade. Verbis ${ }^{23}$ :

$\S 7^{\circ}$ Realizado o acordo na forma do $\S 6^{\circ}$, o respectivo termo, acompanhado das declarações do colaborador e de cópia da investigação, será remetido ao juiz para homologação, o qual deverá verificar sua regularidade, legalidade e voluntariedade, podendo para este fim, sigilosamente, ouvir o colaborador, na presença de seu defensor.

Da leitura acima se observa que, para a homologação do acordo, o magistrado/relator haverá de tomar em conta três requisitos básicos: a regularidade, a legalidade e a voluntariedade.

A regularidade do acordo de colaboração está na presença dos elementos de existência do negócio jurídico e realizar o controle da estrutura formal do instrumento negocial (CAPEZ, 2019, p. 2019).

Já a legalidade, se refere à harmonização do conteúdo das cláusulas pactuadas com o ordenamento jurídico em geral, desde a Constituição Federal, passando pelos tratados internacionais dos quais o Brasil tomou parte, bem como pelas leis infraconstitucionais.

Conforme Vinícius Gomes de Vasconcellos, em oposição à prática que tem se tornado comum no campo jurídico-penal brasileiro (e o caso aqui em estudo parece ser um exemplo disso), a justiça criminal negocial no processo penal precisa necessariamente respeitar os critérios definidos na legislação, em atenção à legalidade, fomentando um modelo limitado de acordos no âmbito criminal (VASCONCELLOS, 2018, p. 164).

Por fim, a voluntariedade, podendo o juiz/relator - como inclusive ocorreu no caso aqui em estudo -, ouvir o colaborador para verificar se de fato é de sua livre vontade cooperar com as autoridades públicas na persecução penal, devendo-se verificar a capacidade do réu de estar em juízo, de modo a assegurar a sua imputabilidade e, após, aferir acerca da liberdade do seu agir, não podendo a colaboração premiada ser fruto de coação, seja física ou psíquica ${ }^{24}$, ou de promessas ilegais não previstas no acordo (VASCONCELLOS, 2018, p. 150).

\footnotetext{
${ }^{23}$ Idem.

${ }^{24}$ Um exemplo dessa práxis está no parecer de um dos integrantes do Ministério Público Federal perante o Tribunal Regional Federal da $4^{\mathrm{a}}$ Região, Procurador Regional da República Manoel Pastana, nos autos do HC n. 5029050-46.2014.404.0000: “A conveniência da instrução criminal mostra-se presente não só na cautela de impedir que os investigados destruam provas, o que é bastante provável no caso dos pacientes, que lidam com o pagamento a vários agentes públicos, mas também na possibilidade de a segregação influenciá-los na vontade de colaborar na apuração de responsabilidade, o que tem se mostrado bastante fértil nos últimos tempos".
} 
Segundo Marcos Paulo Dutra Santos, depois de chancelado o acordo e confirmadas as informações prestadas pelo colaborador, surge para este o direito subjetivo à premiação, competindo ao juiz, na sentença, selecionar o(s) benefício(s), dentre os listados em lei (SANTOS, 2019, p. 171).

Essa posição doutrinária trazida por Santos, acerca do momento e da postura do magistrado, ao decidir a respeito de qual(is) do(s) benefício(s) acordados será levado em conta e aplicado, o que fará na sentença - e não na decisão que homologa o acordo e muito menos no próprio instrumento do mesmo -, já fornece uma ideia de resposta para o problema aqui posto, o que será visto no item subsequente.

\section{VÍCIOS DE CONSTITUCIONALIDADE E LEGALIDADE PELA ANTECIPAÇÃO} DA PENA NOS ACORDOS DE COLABORAÇÃO PREMIADA REGIDOS PELA LEI

\subsection{0/2013}

Um dos principais pontos destacados na decisão proferida pelo Ministro relator Ricardo Lewandowski, no Supremo Tribunal Federal, e que motivou a não-homologação do acordo, foi que este violou o devido processo legal, haja vista que, ao estabelecer de forma antecipada a pena, descurou-se do que diz a Constituição Federal e as leis penais a respeito desse princípio.

Sublinhou o Relator que, ao tempo da lavratura do instrumento do pacto sequer havia processo judicial instaurado, inexistindo acusação formalizada e, portanto, não poderiam as partes, desde logo, estabelecer por acordo a imposição de reprimendas penais ao colaborador (pena privativa de liberdade e restritiva de direitos).

Quando muito, sustentou, o Ministério Público poderia, dentro dos parâmetros firmados pela Lei 12.850/2013 (artigo $4^{\circ}, \S 4^{\circ}$ ), deixar de oferecer denúncia ao colaborador caso algum dos resultados previstos no caput do mesmo artigo se materializasse ao largo das investigações (vide p. 23 da decisão).

No art. $5^{\circ}$, LIV, da Constituição Federal, está estabelecido o devido processo legal, nos seguintes termos: "LIV - ninguém será privado da liberdade ou de seus bens sem o devido processo legal;”. Esse princípio apresenta um complexo de outros mandados, todos integrados em torno da proteção do indivíduo contra o arbítrio do Estado, representado por uma série de garantias espalhadas pelo ordenamento jurídico, desde a Constituição Federal, até as leis e

Disponível em: Disponível em: < https://www.conjur.com.br/dl/lava-jato-parecer-mpf-prisao-forcar.pdf>. Data do acesso: 19 de agosto de 2019. 
demais atos regulatórios, o que engloba: (1) direito ao contraditório e à ampla defesa, de (2) direito ao juiz natural, de (3) direito a não ser processado e condenado com base em prova ilícita, de (4) direito a não ser preso senão por determinação da autoridade competente e na forma estabelecida pela ordem jurídica (MENDES, 2009, p. 685).

Para Celso Antonio Bandeira de Mello, privar da liberdade ou da propriedade não é apenas simplesmente elidi-las, "mas também o é suspender ou sacrificar quaisquer atributos legítimos inerentes a uma ou a outra; vale dizer: a privação não precisa ser completa para caracterizar-se como tal" (MELLO, 2000, p. 85).

Do modo que fixaram o acordo, mesmo sem que existisse uma acusação formalizada $^{25}$, a pena privativa de liberdade, assim como o seu quantum e regime de cumprimento, já haveriam sido previamente definidos no instrumento do pacto, pretendendo que a decisão homologatória fizesse as vezes da condenação, usurpando competências que são constitucionalmente atribuídas ao Estado-Juiz e que não poderiam ser redistribuídas aos sujeitos ativos dos acordos de colaboração premiada pela via da lei ordinária.

Neste aspecto, J.J. Gomes Canotilho e Nuno Brandão lembram que, na fase présentencial, a lei 12.850/2013, em seu artigo $4^{\circ}$, prevê que podem ser aplicadas ao colaborador quatro benefícios: perdão judicial, redução da pena privativa de liberdade em até dois terços, substituição da pena restritiva de liberdade por restritiva de direitos e, finalmente, caso o colaborador não seja o líder da organização criminosa, o Ministério Público pode deixar de oferecer a denúncia e, caso a colaboração se dê após a sentença, tanto a pena poderá ser reduzida até a metade como poderá haver a progressão de regime, mesmo que não preenchidos os requisitos legais objetivos.

Por isso, pontuam que o prévio acerto entre as partes acerca das penalidades e seus desdobramentos não são admitidos juridicamente, porquanto existe:

uma proibição de combinação dos esquemas processuais desenhados na lei que, na
prática, redunde na criação jurisprudencial de soluções que não se ajustem aos
modelos procedimentais cunhados legalmente (CANOTILHO, 2016, p. 30).

Pontificam também que como a Lei $12.850 / 2013$ prevê um mecanismo processual próprio para subtrair o réu colaborador à ação penal, não pode ele (o procedimento) "ser subvertido e contornado através da criação de mecanismos sem sustentação legal destinados a

\footnotetext{
${ }^{25}$ Bem como a oportunidade de exercício do contraditório e da ampla defesa, também não havendo a colheita de provas suficientes a incriminar o colaborador e, finalmente, a despeito da inexistência de sentença condenatória transitada em julgado...
} 
alcançar o resultado para o qual a lei previu uma via processual própria" (CANOTILHO, 2016, p. 34) e, portanto, se chegaria a esse mesmo resultado prescindindo da reunião dos pressupostos de validade estabelecidos pela lei para conceder tal vantagem, concluindo: “A fraude à lei aí perceptível revela à saciedade a violação do princípio constitucional da legalidade processual" (Idem).

Aury Lopes Jr., argumenta, inclusive, que "o respeito às garantias fundamentais não se confunde com impunidade, e jamais se defendeu isso. O processo penal é um caminho necessário para chegar-se, legitimamente, à pena” (LOPES Jr, 2018, p. 35).

Quanto à violação do princípio da legalidade, no plano do direito material, é preciso ter em mente que Canotilho e Brandão lembram que a Lei 12.850/2013 (art. $4^{\circ}$, caput) disciplina o momento em que os benefícios nela previstos poderão ser concedidos ao colaborador, ou seja: apenas na sentença final.

Por tais razões, rememora-se que uma das faces da natureza jurídica da colaboração premiada é constituir uma causa de diminuição/substituição de pena, que se verificará na terceira fase do chamado sistema trifásico desenhado no Código Penal (art. 68), como já visto.

É por isso que o Ministro Ricardo Lewandowski considerou como uma das causas para a não homologação do acordo, a não observância do modo como a legislação penal brasileira estabelece a aplicação de uma penalidade criminal, não se afigurando aceitável a sua imposição por outras vias.

Além disso, o princípio do juiz natural teria sido malferido com a prévia fixação da pena (ou até mesmo a concessão de benefícios legais) ao colaborador desde o acordo. Conforme Aury Lopes Jr., o princípio do juiz natural "não é mero atributo do juiz, senão um verdadeiro pressuposto para a sua própria existência” (LOPES Jr., 2018, p. 60), significando, na forma como a Constituição Federal preceitua, que "ninguém será processado nem sentenciado senão pela autoridade competente" (art. 5', inciso LIII) e, ao mesmo tempo, que "não haverá juízo ou tribunal de exceção" (art. 5, inciso XXXVII).

Em conclusão, neste ponto, cabem mais uma vez as lições de Nereu José Giacomolli, para quem:

[...] a aplicação de sanção criminal fora do processo criminal geraria um estado de exceção no âmbito criminal. Assim como a pena criminal pressupõe a tipicidade, no plano material, a aplicação da sanção penal pressupõe um processo criminal (nulla poena sine judicio), conduzido por um juiz (aspecto processual). (GIACOMOLLI, 2016, p. 468) 
Convém observar, no plano ético, que quando o Estado pactua acordos com membros de organizações criminosas, de certo modo ele se coloca na mesma posição daquele que ele próprio declara como sendo um outsider, um fora da lei, o que coloca em xeque a posição do Estado como esfera de racionalidade da vontade coletiva.

Tomando-se tal realidade em conta e considerando que o Estado, num primeiro momento, tomaria as revelações do colaborador como verdadeiras, prometendo-lhe contrapartidas, Víctor Gabriel Rodríguez questiona:

\begin{abstract}
Muito adiante de investigar quanto um delator pode ser induzido a mentir, está (i) saber se o Estado pode negociar com o crime, descobrir se é possível barganhar com a punição que antes era irrenunciável, (ii) conhecer o que se deve alterar na interpretação do resto do universo das figuras do ordenamento jurídico penal, já que muitas delas apontam para a reprovação de comportamentos como a traição (RODRÍGUEZ, 2018, livro eletrônico Kindle, posição 316).
\end{abstract}

No entanto, ainda assim o Estado prefere fazê-lo por razões utilitárias e econômicas, porquanto é seria infinitamente menos custoso e eficaz utilizar-se de medidas persecutórias negociadas. Mais, se o colaborador previamente não souber qual será o resultado (benefícios concretos) de sua colaboração ${ }^{26}$ dificilmente irá cooperar, ainda que isso implique a violação de deveres éticos estatais, bem como signifique a renúncia pelo Ministério Público do seu poder-dever da persecução penal.

É neste quadrante que calha o estudo de outro princípio, trazido por Zaffaroni, Batista, Alegia e Slokar, que é o da superioridade ética do Estado. Verbis:

À medida que o Estado de Direito cede às pressões do Estado de Polícia,
encapsulado em seu seio, ele perde racionalidade e enfraquece sua função de
pacificador social, mas ao mesmo tempo perde nível ético, porque acentua a
arbitrariedade da coação. Porém, à margem desse declínio moral relativamente
frequente, o certo é que o estado perde por completo sua eticidade quando legitima
formas de coação que ferem a ética de modo direto e inquestionável. Por isso, o
Estado de Polícia não tem nível ético distinto do Estado explicitamente criminal,
mantendo com este apenas uma diferença quantitativa, jamais qualitativa. [...] A
perspectiva de todo Estado de Polícia é sempre a guerra civil (ZAFFARONI, 2011,
p. 243).

No mesmo sentido, a respeito da colaboração premiada e os limites éticos da atuação dos agentes e órgãos estatais, Cezar Roberto Bitencourt questiona:

\footnotetext{
${ }^{26}$ Em entrevista dada à imprensa acerca da decisão do Ministro Lewandowski, o ex-Procurador-Geral da República, Rodrigo Janot, assim se pronunciou: "Não haverá mais negociações. Ninguém entrega o que tem pela promessa futura e incerta do que virá. Isso não é negociação. É imposição. Não faz parte do estado democrático. É o Estado impondo à força o que quer a seus investigados [...]". Disponível em: https://oglobo.globo.com/brasil/decisao-sobre-delacao-premiada-de-marqueteiro-opoe-ministros-do-stf-janot-122077965. Acesso em: 29 de julho de 2019.
} 
Venia concessa, será legítimo o Estado lançar mão de meios antiéticos e imorais, como estimular a deslealdade e traição entre parceiros, apostando em comportamentos dessa natureza para atingir resultados que sua incompetência não lhe permite através de meios mais ortodoxos? (BITENCOURT, 2017).

Não se crê, nos limites desse artigo, no discurso da "incompetência" do Estado na persecução penal. Muito menos no discurso da necessidade de medidas de exceção para combater a "superioridade de armas" do crime em face do Estado. Em verdade, o que se percebe é uma escalada do poder punitivo sobre garantias constitucionais do Estado de Direito acompanhada de uma retórica de terror e medo com a finalidade de gerar convencimentos sociais em torno de medidas restritivas de direitos humanos e fundamentais.

Portanto, a despeito da retórica de utilidade e eficiência da colaboração premiada na persecução penal, o que se verifica quando a autoridade pública e o colaborador, no momento da pactuação do negócio, decidem quais serão os benefícios concedidos e os limites das penas aplicadas, é que esse expediente pode estar violando importantes princípios da nossa tradição jurídico-constitucional e legal (devido processo legal, legalidade, juiz natural e superioridade ética do Estado), sendo prudente que o Poder Judiciário (como fez o Ministro Ricardo Lewandowski, nos autos da Petição 7.265-DF) abster-se de homologar acordos dessa natureza que contenham cláusulas e condições similares.

A colaboração premiada no Brasil, na formatação que lhe conferiu a Lei 12.850/2013, ainda está por ser submetida a um controle de constitucionalidade mais efetivo, já que as dúvidas em torno de sua compatibilidade com o ordenamento jurídico brasileiro tem sido levantadas por setores importantes da doutrina nacional.

\section{CONSIDERAÇÕES FINAIS}

O instituto da colaboração premiada, disciplinado pela Lei 12.850/2013, largamente utilizado no âmbito da Operação Lava Jato, é um expediente unilateral do Ministério Público (e da autoridade policial) na persecução penal, sob o discurso de potencializar as investigações e combater crimes cometidos por organizações criminosas, além de oferecer segurança jurídica ao candidatos a colaborador.

Todavia, tem sido prática recorrente, assim como se passou no acordo firmado entre o Ministério Público Federal e Renato Barbosa Rodrigues Pereira (autos da Petição 7.265DF), ora em estudo, a prévia fixação da pena privativa de liberdade, seu quantum, seu regime 
de cumprimento e prazo prescricional, o que tem sido criticado pela doutrina especializada no assunto.

Inspirada em institutos penais estrangeiros, especialmente no plea bargain norteamericano, essa forma de trabalho ofende diversos princípios constitucionais elencados na Constituição Federal de 1988, a começar pelo devido processo legal, haja vista que, mesmo sem uma acusação formal, sem defesa ampla e técnica, sem a colheita de provas e, finalmente sem que haja uma sentença condenatória transitada em julgado, o colaborador já antecipadamente aceita cumprir uma determinada pena, além de outras sanções e/ou benefícios.

As violações também passam pelo princípio da legalidade, porquanto, além de a Lei 12.850/2013 não autorizar expressamente que as partes assim procedam, ainda há manifesto desrespeito ao sistema trifásico de aplicação da pena, como se encontra no Código Penal (artigo 68), atribuindo, por via infraconstitucional ao Ministério Público ou a Polícia a definição de sanções penais que constitucionalmente foram atribuídas ao Estado-juiz.

Outro princípio relegado, a partir de tal expediente, seria o do juiz natural, na medida em que o magistrado responsável pela sindicalidade do acordo, além de estar, segundo a Lei 12.850/2013, restrito à análise meramente formal dos termos pactuados (voluntariedade, legalidade e regularidade), não teria competência para, via decisão homologatória, dar foros de definitividade para as sanções/benefícios entabulados pelas partes de modo a vincular o julgamento em definitivo da imputação a ser futuramente realizado na sentença final.

Por fim, o princípio da superioridade ética do Estado também estaria malferido, isto porque, em que pese a dificuldade do Ente estatal de lograr que o candidato a colaborador coopere com os agentes públicos caso previamente inexistam limites estabelecidos para as possíveis penalidades aplicáveis, o faz por meios de eticidade duvidosa, na medida em que fomentaria a traição como modo de lograr procedimentos de cunho garantista constitucionalmente definidos para a imposição de uma sanção de natureza criminal.

De maneira que, respondendo à indagação inicial que constituiu o problema da pesquisa, se pôde aferir que o ordenamento jurídico brasileiro não permitiria que, de modo prévio e antecipado, se estabeleçam cláusulas em acordos de colaboração premiada regulamentados pela Lei 12.850/2013 nas quais desde o início estejam pré-fixados as penas, o quantum, o regime, o prazo de prescrição e demais sanções e/benefícios ao colaborador, sendo tais cláusulas nulas de pleno direito, não se prestando a serem homologadas. 
Por isso, o Ministro Ricardo Lewandowski, nos autos da Petição 7.265/DF, ao não homologar o acordo firmado entre o Ministério Público Federal e o colaborador, o fez de modo acertado juridicamente, devendo servir de decisão paradigmática a casos similares doravante submetidos para homologação pelo Poder Judiciário.

\section{REFERÊNCIAS}

BITENCOURT, Cezar Roberto. Delação premiada é favor legal, mas antiético. Disponível em: https://www.conjur.com.br/2017-jun-10/cezar-bitencourt-delacao-premiada-favor-legalantietico. Acesso em 29 de julho de 2019.

BRASIL, Constituição Federal de 1988. Disponível em: <http://www.planalto.gov.br/ccivil_03/Constituicao/Constituicao.htm>.

BRASIL, Lei 12.850/2013. Disponível em: <http://www.planalto.gov.br/ccivil_03/_Ato20112014/2013/Lei/L12850.htm>.

BRASIL, Supremo Tribunal Federal, HC 127.483/PR, Plenário, rel. Ministro Dias Toffolli, 27/08/2015. Disponível em: <www.stf.jus.br>.

BRASIL, Supremo Tribunal Federal, decisão da Petição 7.265/DF, Relator Ministro Ricardo Lewandowski, 14 de novembro de 2017. Disponível em: 〈www.stf.jus.br〉.

CALLEGARI, André Luís. Colaboração premiada: lições práticas e teóricas: de acordo com a jurisprudência do Supremo Tribunal Federal. In: CALLEGARI, André Luís; LINHARES, Raul Marques. Porto Alegre: Livraria do Advogado, 2019.

CANOTILHO, J. J. Gomes; BRANDÃO, Nuno. Colaboração premiada e auxílio judiciário em matéria penal: a ordem pública como obstáculo à cooperação com a operação Lava Jato. Revista de Legislação e Jurisprudência. Ano 146, n. 4000, 2016.

CASTRO, Ana Lara Camargo de. Plea bargain: resolução penal pactuada nos Estados Unidos. Belo Horizonte: D’Plácido, 2019.

CASTRO, Matheus Felipe de. Abrenutio Sanatae! A colaboração premiada na Lei n. 12.850/2013: um novo paradigma de sistema penal contratual? Revista de Estudos Criminais, Porto Alegre, volume 17, n. 69, 2018, p. 171-219.

FILIPPETTO, Rogério. ROCHA, Luísa Carolina Vasconcelos Chagas. Colaboração premiada: contornos segundo o sistema acusatório. Belo Horizonte: Editora D’Plácido, 2017.

GIACOMOLLI, Nereu José. Legalidade, oportunidade e consenso no Processo Penal na perspectiva das garantias constitucionais: Alemanha, Espanha, Itália, Portugal e Brasil. Porto Alegre: Livraria do Advogado, 2006.

. O devido processo penal: abordagem conforme a Constituição Federal e o Pacto de São José da Costa Rica. 3. ed. São Paulo: Atlas, 2016.

LOPES Jr, Aury. Direito Processual Penal. 15. Ed. São Paulo. Saraiva, 2018.

MELLO, Celso Antonio Bandeira de. Curso de Direito Administrativo. 12. ed. São Paulo: Malheiros, 2000.

MENDES, Gilmar Ferreira; BRANCO, Gustavo Gonet. Curso de Direito Constitucional. 4. ed. São Paulo: Saraiva, 2009. 
PACELLI, Eugênio. Manual de direito penal: parte geral. 4. ed. São Paulo: Atlas, 2018.

RODRÍGUEZ, Víctor Gabriel. Delação premiada: limites éticos ao Estado. Rio de Janeiro: Forense, 2018, livro eletrônico (Kindle), posição 316.

SANTOS, Marcos Paulo Dutra. Colaboração (delação) premiada. 3. ed. Salvador: Juspodivm, 2019.

VASCONCELLOS, Vinícius Gomes de. Colaboração premiada no processo penal. 2. ed. São Paulo: Thomson Reuters Brasil, 2018.

ZAFFARONI, Eugênio Raúl et. al. Direito Penal brasileiro: primeiro volume - Teoria Geral do Direito Penal. 4. ed. Rio de Janeiro: Revan, 2003. 